\title{
EFFECT OF OZONE AND AUTOHYDROLYSIS PRETREATMENTS ON ENZYMATIC DIGESTIBILITY OF COASTAL BERMUDA GRASS
}

\author{
Jung Myoung Lee, Hasan Jameel, and Richard A. Venditti * \\ Coastal Bermuda grass (CBG) has been shown to have potential as a \\ biomass feedstock for sugar production. In this study, the effectiveness \\ of ozone pretreatment for CBG to improve the sugar recovery via \\ enzyme hydrolysis was investigated. Raw CBG and autohydrolysis- \\ treated CBG were pretreated with ozone at ozone consumption of 1.8 to \\ $26.4 \%(\mathrm{w} / \mathrm{w})$ at room temperature. Lignin degradation and hemi- \\ cellulose solubilization increased with increased ozone consumption. At \\ 26.4\% ozone consumption by weight on CBG the amount of lignin in the \\ CBG was reduced by $34 \%$. Autohydrolysis of CBG increased the \\ reactivity of cellulose, hemicellulose, and lignin with ozone. The \\ maximum total sugar recovery after enzymatic hydrolysis was $32 \%$ for a \\ $14.0 \%$ consumption of ozone on raw CBG. For CBG samples pretreated \\ with autohydrolysis followed by a $3.1 \%$ ozone consumption pretreatment \\ the maximum total sugar recovery after enzyme hydrolysis was $40.1 \%$. \\ Autohydrolysis pretreatment followed by enzyme hydrolysis yielded a \\ $36.4 \%$ sugar recovery, indicating that the application and benefits of \\ ozone after autohydrolysis with the conditions studied herein are \\ marginally better than autohydrolysis alone.
}

Keywords: Autohydrolysis; Coastal Bermuda Grass; Ethanol; Enzymatic Hydrolysis; Ozone pretreatment

Contact information: Department of Forest Biomaterials, North Carolina State University, Campus Box 8005, Raleigh, NC 27695-8005 USA; *Corresponding author: Richard_venditti@ncsu.edu

\section{INTRODUCTION}

Lignocellulosic materials such as agricultural, industrial, and urban residues are a potential source to produce low cost energy and fuels (US-DOE 2005). Extensive research has been done on the conversion of lignocellulosics into ethanol (Hendriks and Zeeman 2009). Bioethanol production with lignocellulosic materials by biochemical conversion involves two processes, enzymatic hydrolysis of carbohydrate in the feedstock to fermentable sugars and fermentation of the sugars to ethanol through yeast or bacteria (Mosier et al. 2005). In order to increase the efficiency of the conversion, various pretreatment technologies have been extensively examined with respect to the physico-chemical factors that make the substrate more easily accessible to the enzyme and decrease the recalcitrant structure of the biomass (Coughlan 1992). Effective pretreatment technologies should (1) result in efficient sugar generation at low enzyme consumption, (2) not cause significant loss or degradation of carbohydrates, (3) not form byproducts that inhibit subsequent hydrolysis and fermentation processes, and (4) be cost effective (Sun and Cheng 2002).

Ozone is a highly reactive allotrope of oxygen, and its applications since 1949 have 
been extensively reviewed (Liebergott and van Lierop 1978). Ozonolysis has been used to pretreat a number of lignocellulosic materials to increase the nutritive value for ruminants, including wheat straw (Ben-Ghedalia and Miron 1981), woody biomass including pine, oak, and poplar and agricultural residues including wheat straw, peanut, corn stover and bagasse (Neely 1984), cotton straw (Ben-Ghedalia and Shefet 1983), and coastal Bermuda grass and Kentucky-31 fall fescue (Akin and Morrison 1988). In recent years, ozonolysis pretreatment has been evaluated for enhancement of enzymatic susceptibility of lignocellulosic materials including poplar sawdust (Vidal and Molinier 1988), wheat and rye straw (Carcia-Cubero et al. 2009), wastepaper (Kojima and Yoon 2008), cotton stalk (Silverstein et al. 2007), and corn stalk (Quesada et al. 1999). The effect of ozone on enzyme accessibility with coastal Bermuda grass is still unreported.

Ozone is highly effective in the removal of lignin, slightly degrades hemicellulose, but hardly affects cellulose (Sun and Cheng 2002). Hence, it produces less toxic degradation products that may interfere with subsequent enzymatic hydrolysis and fermentation. Further, ozone reactions can be performed at ambient temperature and pressure (Vidal and Molinier 1988). In spite of this, ozonolysis has not been widely accepted as a viable option for biomass pretreatment due to the inefficiency of ozone generators to produce ozone in an economical process. However, ozone generation costs are decreasing and the cost for pretreatment might be feasible for enzymatic hydrolysis since ozone is highly reactive with lignocellulosic biomass (Kojima and Yoon 2008). Currently it is estimated that ozone costs approximately $\$ 0.80$ per pound. Additional capital cost savings are also possible for an ozone pretreatment system because the reactions occur at room temperature.

Coastal Bermuda grass $(\mathrm{CBG})$ is a readily available source of carbohydrates that often is planted as a method to remediate waste. CBG has been shown to have considerable promise as a feedstock for sugar production with autohydrolysis pretreatment, also known as hydrothermal pretreatment, and ammonia fiber explosion (AFEX) pretreatment (Lee et al. 2009, 2010). The autohydrolysis process, in which water is the only media, on CBG provides a simple, low cost and environmentally friendly pretreatment technology for sugar generation (Lee et al. 2009). In autohydrolysis of CBG the lignin content was slightly decreased (4\%) regardless of severity, and a significant amount of the hemicellulose $(83.3 \%)$ was extracted at the most severe condition $\left(170^{\circ} \mathrm{C}\right.$ for $\left.1 \mathrm{~h}\right)$. In addition, increasing severity of autohydrolysis pretreatment of $\mathrm{CBG}$ generated more monosaccharide in the prehydrolyzate and less oligomeric sugar. Higher severity conditions also degraded sugars to byproducts such as acetic acid and furfural-related compounds. Autohydrolysis at $150{ }^{\circ} \mathrm{C}$ for $60 \mathrm{~min}$ generated $70 \%$ of the theoretical sugar yield from $\mathrm{CBG}$ (combined sugar in autohydrolysis filtrate and enzymatically treated solid residue) (Lee et al. 2009). In order to improve the conversion efficiency of autohydrolysis followed by enzymatic hydrolysis, ozone treatment of autohydrolysis-pretreated feedstock may be beneficial due to a possible removal of lignin, which may hinder the accessibility of enzymes. In this research, the effectiveness of ozone as a pretreatment technique for enzymatic saccharification of raw and autohydrolysis-treated CBG is determined. 


\section{EXPERIMENTAL}

\section{Biomass}

Coastal Bermuda grass (CBG) was collected in early 2007 from Cunningham Research Station (Kinston, NC). The stalk with 10\% initial moisture content (MC) was shredded to 2-4 inch lengths and stored in an air-tight container in a cold room $\left(4^{\circ} \mathrm{C}\right)$ prior to experiments. The shredded feedstock was further ground in a Thomas Wiley Laboratory Mill (Model No. 4, Thomas Scientific, Philadelphia, PA) to pass through a 2 $\mathrm{mm}$ sieve for ozone pretreatment. The material passed through a 20 mesh screen $(0.85$ $\mathrm{mm}$ sieve size opening) and retained on a 40 mesh screen $(0.38 \mathrm{~mm}$ sieve size opening) was collected for compositional analysis and brightness measurement.

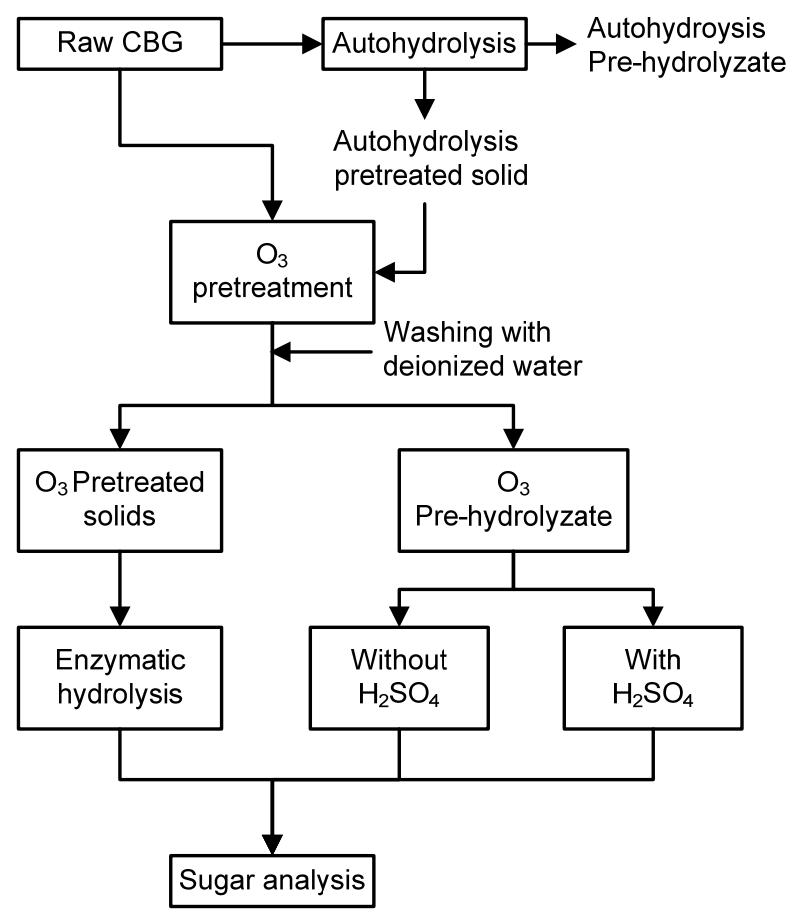

Fig. 1. Experimental process flow diagram of autohydrolysis and ozonolysis. In order to convert oligomeric sugars in the $\mathrm{O}_{3}$ pre-hydrolyzate into monomeric sugars, the pre-hydrolyzate was subjected to a post-hydrolysis with $4 \%$ w/w sulfuric acid for $1 \mathrm{~h}$ at $121^{\circ} \mathrm{C}$ (with $\mathrm{H}_{2} \mathrm{SO}_{4}$ )

\section{Pretreatment}

The ground raw $\mathrm{CBG}$ and autohydrolysis-pretreated $\mathrm{CBG}$ were used as the feedstock for ozone pretreatment in this study as depicted in Fig. 1.

In order to prepare autohydrolysis-pretreated CBG sample, the CBG samples (100 oven dry (o.d.) grams) were loaded into a $1.5 \mathrm{~L}$ stainless steel rotating bomb digester (Thermcraft, Winston-Salem, NC) and supplemented with an appropriate amount of deionized water to make a final solid to liquid ratio of 1:6. Autohydrolysis pretreatment was performed at $150^{\circ} \mathrm{C}$ for $60 \mathrm{~min}$ (after the pre-determined digester temperature was reached, heating ramp time of about 30 minutes), which showed the highest overall sugar yield based on previous results (Lee et al. 2009). Pretreated samples were cooled to room 
temperature and filtered through cheese cloth. The original filtrates were collected for solids contents, $\mathrm{pH}$ measurement, and sugar analysis. The remaining solid was collected for ozone pretreatment.

The ground raw CBG, prior to ozone pretreatments, was moistened to $30 \%$ with an appropriate amount of deionized water and stored in an air-tight container overnight in order to even the moisture distribution in the samples. Ozone pretreatments were carried out at room temperature in a batch mode. The ozone system was constructed with an oxygen tank, an ozone generator (Model GL-1, PCI Ozone \& Control Systems Inc., West Caldwell, NJ), and a rotary evaporator (flash-evaporator, Buchler Instruments, Fort Lee, NJ) fitted with a rotating 3L round-glass flask, as illustrated in Fig. 2. Unreacted ozone in the effluent gas was collected in a gas absorber that contained $2 \%$ potassium iodide (KI) solution. On average, approximately $80 \%$ of the ozone supplied to the reactor reacted.

Ozone was produced by passing pure oxygen, at an operating pressure of 0.5 $\mathrm{kg} / \mathrm{cm}^{2}$, through the ozone generator. Approximately an $8 \%$ ozone by weight gas was produced at the instrument setting of $25 \%$ of ozone output and monitored using an ozone monitor (Model HC, PCI Ozone \& Control Systems Inc., West Caldwell, NJ). The ozonized gas stream from the ozone generator was continuously fed through the rotary reactor with a flow rate of 1.0 liter/min. Prior to the start of a run, the ozone generated from the ozone generator was passed through the bypass line for 10 minutes to obtain a constant level of ozone production. At the end of the reaction, the ozone generator was switched off, and the system was flushed for 5 minutes with oxygen gas. In order to calculate the amount of unreacted ozone, the aliquot $(10-50 \mathrm{ml})$ of the ozonized KI solution in the trap connected to the excess ozone line was acidified with $4 \mathrm{~N}$ sulfuric acid $(10 \mathrm{ml})$ in a flask and determined with iodometric titration.

The ozone consumption $(\mathrm{C}$, in equation 3$)$ was calculated from the difference between the amount of ozone supplied (A, in equation 1) and the ozone exiting the reactor $(\mathrm{B}$, in equation 2$)$.

$$
\begin{aligned}
\mathrm{A}(\mathrm{g})= & \frac{\text { Weight } \% \text { of } \mathrm{O}_{3}(\mathrm{~g})}{100(\mathrm{~g})} \times \text { density of } \mathrm{O}_{3}(\mathrm{~g} / \mathrm{l}) \times \text { flow rate of } \mathrm{O}_{3}(\mathrm{l} / \mathrm{t}) \times \text { reaction time }(t) \\
\mathrm{B}(\mathrm{g})= & T \text { consumed }(\mathrm{ml}) \times 0.1(\mathrm{~N}) \times \frac{\text { Molecular wt of } T(\mathrm{~g})}{1000(\mathrm{ml})} \times \frac{\text { total volume of } \mathrm{KI}(\mathrm{ml})}{\text { amount titrated of } \mathrm{KI}(\mathrm{ml})} \times \\
& \frac{1}{\text { Molecular wt of } T}(\text { moles } / \mathrm{g}) \times \frac{1 \text { mole of } \mathrm{O}_{3}}{2 \text { mole of } T} \times \frac{\mathrm{g} \text { of } \mathrm{O}_{3}}{\text { moles of } \mathrm{O}_{3}} \\
\mathrm{C}(\%)= & \frac{(\text { A-B })(\mathrm{g})}{\text { Biomass }(\mathrm{g})} \times 100
\end{aligned}
$$

where A is ozone supplied ( $\mathrm{g}$ ) at given reaction time (min.)

$\mathrm{B}$ is un-reacted ozone $(\mathrm{g})$ with feedstock in reactor at given reaction time (min.)

$\mathrm{N}$ is normality of the sodium thiosulfate solution

$T$ is sodium thiosulfate ( $\mathrm{ml}$ of $0.1 \mathrm{~N}$ solution)

$\mathrm{C}$ is ozone consumption (\%) 
The following ozone consumptions were determined for the corresponding reaction times, raw CBG: 0\% (0 min), 4.5\% (15 min), 14.0\% (30 min), 26.4\% (60 min), and autohydrolysis-pretreated CBG: $0 \%(0 \mathrm{~min}), 1.8 \%(6 \mathrm{~min}), 3.1 \%(11 \mathrm{~min})$. The ozone-pretreated solids were washed with $500 \mathrm{~mL}$ of deionized water, and the ozone prehydrolyzate was collected for determination of total solids, $\mathrm{pH}$ measurement, and sugar analysis. The resultant solids were used for enzymatic hydrolysis.

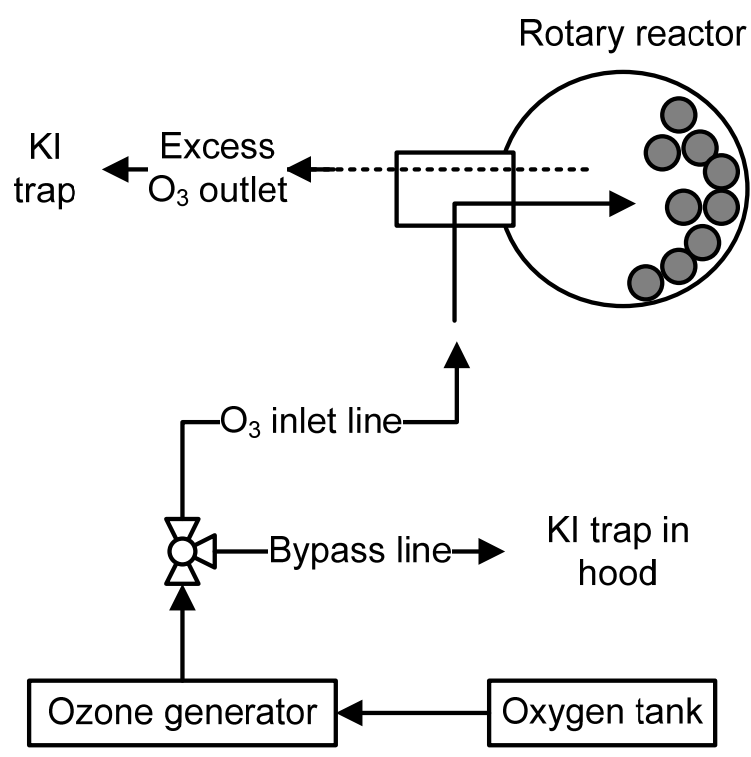

Fig. 2. Schematic diagram of the reaction system employed for the ozonolysis of CBG

\section{Analysis Methods}

The total solids, acid soluble lignin, and acid insoluble lignin content of untreated, autohydrolysis-treated, ozone-treated, and a combination of autohydrolysis and ozone-treated CBG were determined by National Renewable Energy Laboratory's (NREL) Laboratory Analytical Procedures (LAP 001, 003, 004) (Ehrman 1994, 1996; Templeton and Ehrman 1994). Aliquots of $10 \mathrm{ml}$ from each prehydrolyzate were dried at $105^{\circ} \mathrm{C}$ overnight to determine the solids content $(\mathrm{mg} / \mathrm{ml})$. The filtrates were subjected to a hydrolysis with $4 \% \mathrm{w} / \mathrm{w} \mathrm{H}_{2} \mathrm{SO}_{4}$ for 1 hour at $121{ }^{\circ} \mathrm{C}$ to convert oligomers (i.e. xylooligomers) into mono-sugars. All filtrates were filtered through 0.2 um nylon filter before sugar analysis.

The hydrolyzate after the Klason lignin determination was collected and analyzed for sugar concentrations, including arabinose, rhamnose, galactose, glucose, xylose, and mannose. Monosaccharides in the hydrolyzates were determined using an ion chromatography (IC) system (ICS 3000, Dionex Corp., CA) equipped with an AS auto sampler, a GP40 gradient pump, a high-pH anion exchange column (CarboPac ${ }^{\mathrm{TM}}$ PA1, Dionex Corp., Sunnyvale, CA), and an ED40 electrochemical detector. Aliquots $(20 \mu \mathrm{L})$ were injected on the column after passing through a $0.2 \mu \mathrm{m}$ nylon syringe filter (Millex ${ }^{\circledR}$, Millipore Corp., Billerica, MA). The column was eluted with deionized water at a flow rate of $1.0 \mathrm{ml} / \mathrm{min}$. The column was re-conditioned using $0.2 \mathrm{M} \mathrm{NaOH}$ after each analysis. To optimize the baseline stability and detector sensitivity, $0.4 \mathrm{M} \mathrm{NaOH}$ 
was added to a post-column at a rate of $0.1 \mathrm{ml} / \mathrm{min}$. L-(-)-fucose (F2252, Sigma, Saint Louis, MO) was used as an internal standard, and sugar contents were quantified by comparison with standards. All chemical composition experiments were performed in duplicate. The cellulose and hemicellulose contents were calculated using equations 4 and 5 (0.9 is the correction coefficient for hydration, Iyer and Lee 1999).

$$
\begin{aligned}
& \% \text { cellulose }=\frac{\text { glucose released }(\mathrm{g}) \times 0.9}{\text { sample dry weight }(\mathrm{g})} \times 100 \\
& \% \text { hemicellulose }=\frac{\text { hemicellulose released }(\mathrm{g}) \times 0.9}{\text { sample dry weight }(\mathrm{g})} \times 100
\end{aligned}
$$

where hemicellulose released $(\mathrm{g})$ is the summation of arabinose, rhamnose, galactose, xylose, and mannose detected with IC.

Solids recovery was calculated as a percentage of the total recovery (summation of residues and solids in the prehydrolyzate) after pretreatment based on the initial sample (dry weight). Cellulose and hemicellulose reductions were estimated as the ratio of cellulose and hemicellulose remaining in the solids recovered to those in the untreated CBG samples, respectively.

In order to measure optical property changes by ozonolysis, approximately $5 \mathrm{~g}$ of oven-dried samples after ozone treatment was contained in a glass Petri dish, and the GE brightness was measured using a Brightimeter (Model S-4 brightness, Technidyne Corp., New Albany, IN).

\section{Enzymatic Hydrolysis}

Enzyme hydrolysis of pretreated solids was carried out with a mixture of three commercial enzymes, cellulase from Trichoderma reesei (NS-50013, 700 EGU (endoglucanase unit)/g), $\beta$-glucosidase from Aspergillus niger (NS-50010, $250 \mathrm{CBU}$ (cellobiase unit)/g) and xylanase (NS-50014, $750 \mathrm{FXU}$ (fungal xylanase unit)/g) provided by Novozymes (Franklinton, NC, USA). The cellulase enzyme activity was measured to be $75 \mathrm{FPU} / \mathrm{g}$ of cellulases in the lab (Ghose 1987). A fixed cellulase loading (10 FPU/g pretreated solids) was evaluated. The dosage of $\beta$-glucosidase and xylanase supplementation constituted $30 \%$ of the volume of cellulase added (0.3-1 volumetric ratio to cellulase loading).

Five grams of pretreated sample (dry weight) were supplemented with enzyme solutions and then added to a $50 \mathrm{mM}$ acetate buffer $(\mathrm{pH} 4.8)$ to achieve a $5 \% \mathrm{w} / \mathrm{v}$ final solids loading. Sodium azide $(0.3 \%, \mathrm{w} / \mathrm{v})$ was used in the mixture to inhibit microbial contamination. Samples were incubated at $50 \pm 2^{\circ} \mathrm{C}$ in a shaker bath at $180 \mathrm{rpm}$ for $48 \mathrm{~h}$. Hydrolyzed samples were filtered through a pre-weighed filter paper (Whatman No. 4, Whatman International Ltd, Maidstone, UK). Separate experiments showed that no sugars were generated from filter paper when the filter paper is exposed to enzymes already exposed to biomass, data not shown. Aliquots of the supernatants were recovered for sugar analysis. The residual solids were dried in a convection oven at $105^{\circ} \mathrm{C}$ and weighed to calculate percentage weight loss. Also, the chemical compositions of the residual solids were measured, as described in the compositional analysis section. All experiments were carried out in duplicate and the average and range reported. 


\section{RESULTS AND DISCUSSION}

\section{Effect of Ozone Pretreatment on the Chemical Composition of CBG}

The compositional analysis of untreated CBG, autohydrolysis-pretreated CBG at $150{ }^{\circ} \mathrm{C}$ for $60 \mathrm{~min}$, and ozone-treated $\mathrm{CBG}$ of the untreated and autohydrolysis-treated CBG is summarized in Table 1 . The amount of ozone consumption is not directly set but affected by the biomass characteristics and calculated after the experiment. It is difficult to set experimental conditions for different biomass samples apriori that have exactly the same ozone consumption. The untreated sample with $0 \%$ ozone indicates the effect of simple tumbling of the biomass at $30 \%$ moisture in the reactor vessel, which is used as a control for the ozone experiments. The solid recovery yield decreased with percent ozone consumption for both raw CBG and autohydrolysis-pretreated CBG. Autohydrolysis prior to ozone treatment significantly decreased the yields relative to ozone alone treatment.

The cellulose and hemicelluloses content of raw CBG was 55.6\% of the total weight, consisting of glucan $29.5 \%$, xylan $19.8 \%$, arabinan $4.5 \%$, and galactan $1.8 \%$. The difference of chemical compositions between raw and $0 \%$ ozone-treated CBG may be from the sample preparation. Approximately, $6 \%$ of water-soluble components, mainly hemicellulose, from the CBG with $30 \%$ moisture content become solubilized during overnight moisture equilibration. The holocellulose content of ozone-pretreated CBG (26.4\% ozone consumption) was $49.1 \%$, a $7.7 \%$ decrease with respect to the $0 \%$ ozone consumption. The glucan content of ozone-pretreated CBG $(26.4 \%$ ozone consumption) was $32.5 \%$, an only $2.1 \%$ decrease with respect to the $0 \%$ ozone consumption. In contrast, the ozone-pretreated CBG (26.4\% ozone consumption) hemicellulose content decreased by $17.0 \%$ relative to the $0 \%$ ozone consumption. In summary, ozone significantly affected hemicellulose but not cellulose. A significant $31.3 \%$ reduction in lignin was observed with the $26.4 \%$ ozone consumption compared to $0 \%$ ozone consumption.

When comparing the $4.5 \%$ ozone treatment with raw $\mathrm{CBG}$, relative to the autohydrolysis pretreatment followed with $3.1 \%$ ozone pretreatment, the combination of autohydrolysis and ozone resulted in significantly lower lignin, holocellulose, glucan, and hemicellulose in the solids.

The brightness values of raw CBG and autohydrolysis-pretreated CBG after ozonation are summarized in Table 2. With higher ozone consumption to feedstocks, the brightness of the resulting solids was increased up to $66 \%$ compared to the feedstocks. Also, a higher \% increase of brightness was observed with autohydrolysis-pretreated solids at the same ozone consumption. The changes of brightness observed are in agreement with the reduction of residual lignin in the solid samples.

To summarize, ozone pretreatment decreased lignin and hemicellulose content significantly, but not glucan content. Autohydrolysis prior to ozone decreased the overall solids yield compared to the ozone pretreatment alone. 
Table 1. Composition of the Raw Material and of the Solid Residue after Ozone Treatments as Grams of Component Recovered per $100 \mathrm{~g}$ of Raw Material

\begin{tabular}{|c|c|c|c|c|c|c|c|c|}
\hline & \multirow{2}{*}{ Raw } & \multicolumn{4}{|c|}{ Raw CBG } & \multicolumn{3}{|c|}{$\begin{array}{l}\text { Autohydrolysis-pretreated CBG } \\
\qquad\left(150^{\circ} \mathrm{C} \text { for } 60 \mathrm{~min}\right)\end{array}$} \\
\hline & & $0.0 \%$ & $4.5 \%$ & $14.0 \%$ & $26.4 \%$ & $0.0 \%$ & $1.8 \%$ & $3.1 \%$ \\
\hline Total Lignin & $22.7 \pm 0.4$ & $21.7 \pm 0.2$ & $19.9 \pm 0.2$ & $17.6 \pm 0.1$ & $14.9 \pm 0.0$ & $19.2 \pm 0.0$ & $17.0 \pm 0.1$ & $16.4 \pm 0.1$ \\
\hline Holocellulose & $55.6 \pm 0.3$ & $53.2 \pm 0.1$ & $51.3 \pm 0.2$ & $50.0 \pm 0.3$ & $49.1 \pm 0.3$ & $51.0 \pm 0.5$ & $45.6 \pm 0.1$ & $45.8 \pm 0.4$ \\
\hline Glucan & $29.5 \pm 0.5$ & $33.2 \pm 0.2$ & $33.1 \pm 0.2$ & $32.6 \pm 0.4$ & $32.5 \pm 0.2$ & $33.6 \pm 0.6$ & $30.5 \pm 0.1$ & $30.9 \pm 0.6$ \\
\hline Hemicellulose & $26.1 \pm 0.2$ & $20.0 \pm 0.0$ & $18.2 \pm 0.2$ & $17.4 \pm 0.1$ & $16.6 \pm 0.4$ & $17.4 \pm 0.3$ & $15.1 \pm 0.1$ & $14.9 \pm 0.2$ \\
\hline Ash & $4.9 \pm 0.4$ & $1.3 \pm 0.0$ & $1.3 \pm 0.0$ & $1.0 \pm 0.0$ & $1.0 \pm 0.1$ & $0.6 \pm 0.0$ & $1.0 \pm 0.1$ & $1.0 \pm 0.1$ \\
\hline Extractives & $9.8 \pm 0.3$ & $\mathrm{~N} / \mathrm{D}$ & N/D & N/D & N/D & N/D & $\mathrm{N} / \mathrm{D}$ & N/D \\
\hline Others $^{1)}$ & $7.0 \pm 0.1$ & $16.9 \pm 0.0$ & $18.6 \pm 0.0$ & $18.6 \pm 0.0$ & $19.7 \pm 0.0$ & $8.1 \pm 0.0$ & $11.8 \pm 0.2$ & $11.1 \pm 0.2$ \\
\hline Yields ${ }^{2)}$ & 100 & 93.1 & 91.0 & 87.2 & 84.7 & 78.9 & 74.9 & 74.7 \\
\hline
\end{tabular}


Table 2. Brightness Measurement of Residues from Ozone Treatment

\begin{tabular}{|c|c|c|c|c|c|c|c|}
\hline \multirow{2}{*}{$\begin{array}{c}\mathrm{O}_{3} \\
\text { consumption }\end{array}$} & \multicolumn{4}{|c|}{ CBG raw } & \multicolumn{3}{c|}{ CBG from 150 ${ }^{\circ} \mathrm{C}$} \\
\cline { 2 - 8 } & $0 \%$ & $4.5 \%$ & $14.0 \%$ & $26.4 \%$ & $0 \%$ & $1.8 \%$ & $3.1 \%$ \\
\hline Brightness(\%) & $13.0 \pm 0.1$ & $15.1 \pm 0.1$ & $18.6 \pm 0.1$ & $21.6 \pm 0.1$ & $9.3 \pm 0.1$ & $10.4 \pm 0.0$ & $11.1 \pm 0.1$ \\
\hline$\%$ increase $^{1)}$ & - & 15.8 & 42.9 & 65.6 & - & 11.9 & 19.2 \\
\hline${ }^{1)}$ Calculated \% increase based on values of each brightness at 0\% ozone treatment \\
\hline
\end{tabular}

\section{Kinetics of Removal of Chemical Components}

The rate of chemical components removal is proportional to the concentration of components present at time, $t$, and the ozone consumption. The removal of chemical components with ozone pretreatment can be expressed by Equation 6 (Eisenhauer 1971):

$$
\ln \frac{C_{o}}{C_{t}}=k R t
$$

where

$C_{o}=$ the initial component concentration $(\%)$

$C_{t}=$ the component concentration (\%) at time $t(\mathrm{~min})$

$R=$ the ozone consumed ( $\mathrm{g}$ of ozone consumed $/ \mathrm{g}$ of feedstock in $\%$ for the entire reaction time)

$k=$ the rate constant, units of $(\% \mathrm{~min})^{-1}$

It has been known that the rate constant $(k)$ by which chemical components react with ozone is significantly dependent on the $\mathrm{pH}$ of the starting solution. For phenol removal with ozone the value of $k$ increased as the $\mathrm{pH}$ increased from 4 to 7.5 and then remained constant above 7.5 (Gould and Weber 1976). In experiments herein, the $\mathrm{pH}$ of the starting solution was set to 7.0, although ozone is more stable at low pH (Pan et al. 1984).

Plots of the logarithm of $C_{o} / C_{t}$ versus ozone dosage are shown in Fig. 3, for both raw and autohydrolysis-pretreated $\mathrm{CBG}$, as described in Table 1. The reference component compositions of $0 \%$ ozone consumption and raw $\mathrm{CBG}$ were used as the initial component concentration $\left(C_{o}\right)$, for raw $\mathrm{CBG}$ and for autohydrolysis-pretreated $\mathrm{CBG}$, respectively. The plot of the logarithm of lignin content of ozone pretreatment with autohydrolysis-treated CBG showed a strong linear relationship between the lignin reduction and ozone dosage, with the slope resulting in a $k$ value of 0.052 , and $\mathrm{R}^{2}$ value of 0.96 , as shown in Fig. 3. The slope for hemicelluloses was 0.052 with a lower $\mathrm{R}^{2}$ value (0.88). In contrast, the slope for glucan showed the lowest value of 0.029 and the lowest $\mathrm{R}^{2}$ value. 


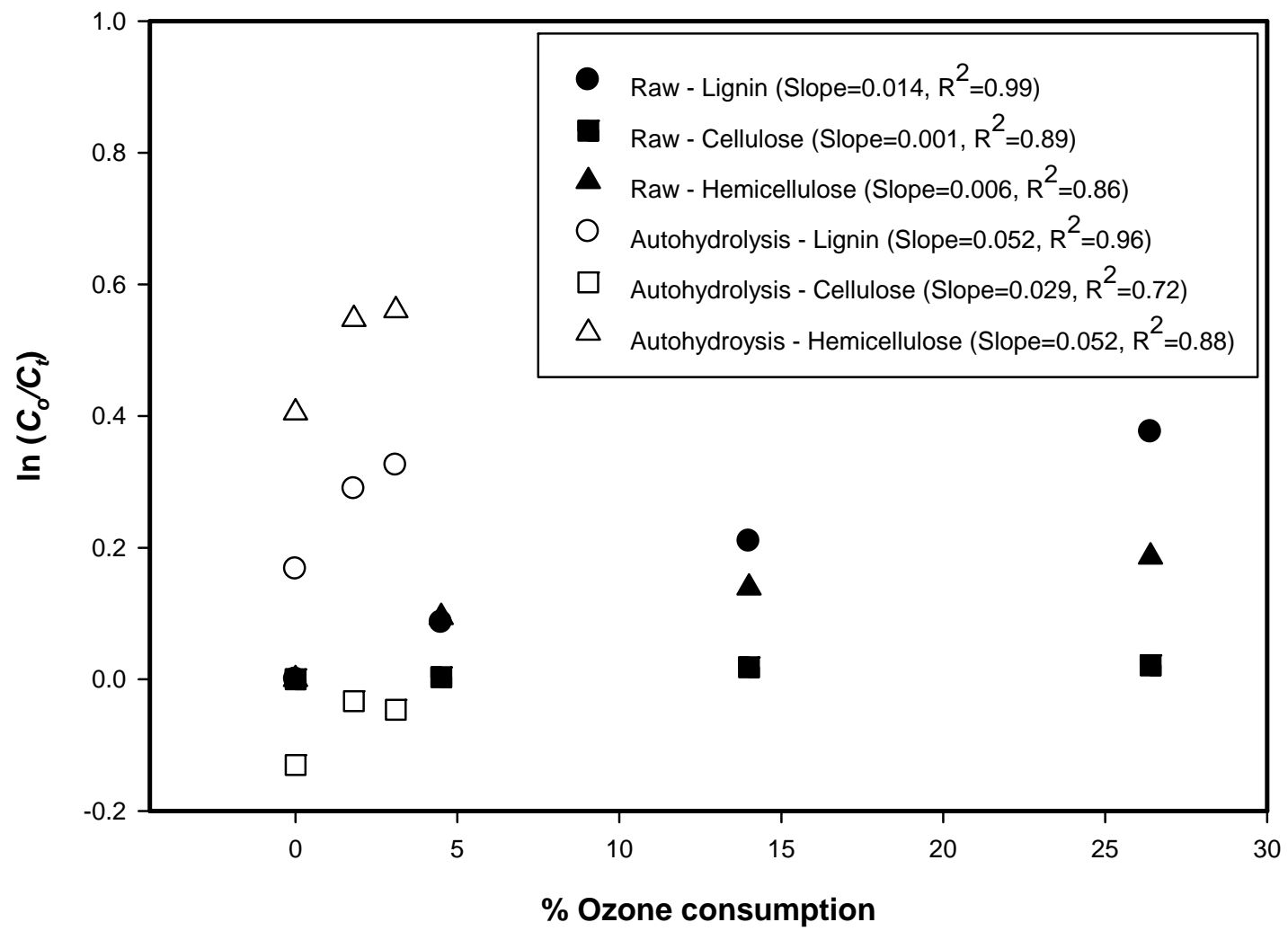

Fig. 3. Removal efficiency of chemical components by ozonolysis

In the case of ozone pretreatment with raw CBGs, all $k$ values of lignin, hemicellulose, and cellulose were significantly lower than those of autohydrolysis-treated CBG. A strong linear relationship was observed for lignin reduction and ozone dosage (slope $=0.014$ and $\mathrm{R}^{2}=0.99$ ), but the plots for hemicelluloses and glucan showed lower rates with 0.006 and 0.001 , respectively. Figure 3 showed that ozone pretreatment caused solubilization of part of the hemicellulose, although the removal efficiency was less than lignin removal, as has been also observed by other authors (Ghedalia and Miron 1981; Sun and Cheng 2002). Cellulose is less reactive with ozone than lignin or hemicellulose.

In general, these observations indicated that the reaction efficiency of autohydrolysis-pre-treated CBG with ozone is higher than that of ozonation of the raw CBG.

\section{Effect of Ozone Pretreatment Conditions on Acidity $(\mathrm{pH})$}

It is well known that ozone is highly reactive towards phenolic compounds and attacks aromatic nuclei selectively, resulting in ring opening (Kratzl et al. 1976). Thus, during ozonolysis, aromatic aldehyde and acids including $p$-hydroxybenzaldehyde, vanillin, vanillic acid, caproic acid, azelaic acid, and $p$-hydroxybenzoic acid are generated from the oxidation products of $p$-coumaric and ferulic acids, which are the main phenolic acids in the CBG (Morrison and Akin 1990). Also lignin-hemicellulose complexes could be solubilized (Sun and Cheng 2002). As shown in Fig. 4, higher ozone dosage leads to higher acidity (lower $\mathrm{pH}$ ). Prior to ozonolysis, CBG samples were 
soaked in deionized water of $\mathrm{pH} 7$. With $0 \%$ ozone consumption, the $\mathrm{pH}$ of the liquid of the CBG suspension decreased to 5.2, suggesting that there are acidic species (phenolic and aliphatic) present in the raw materials or generated from water-soluble hemicellulose and phenolic compounds. Ozone treatment also leads to a $\mathrm{pH}$ decrease from 5.2 to 2.6 at $26.4 \%$ ozone dosage, indicating the generation of phenolic acids from lignin compounds (Morrison and Akin 1990).

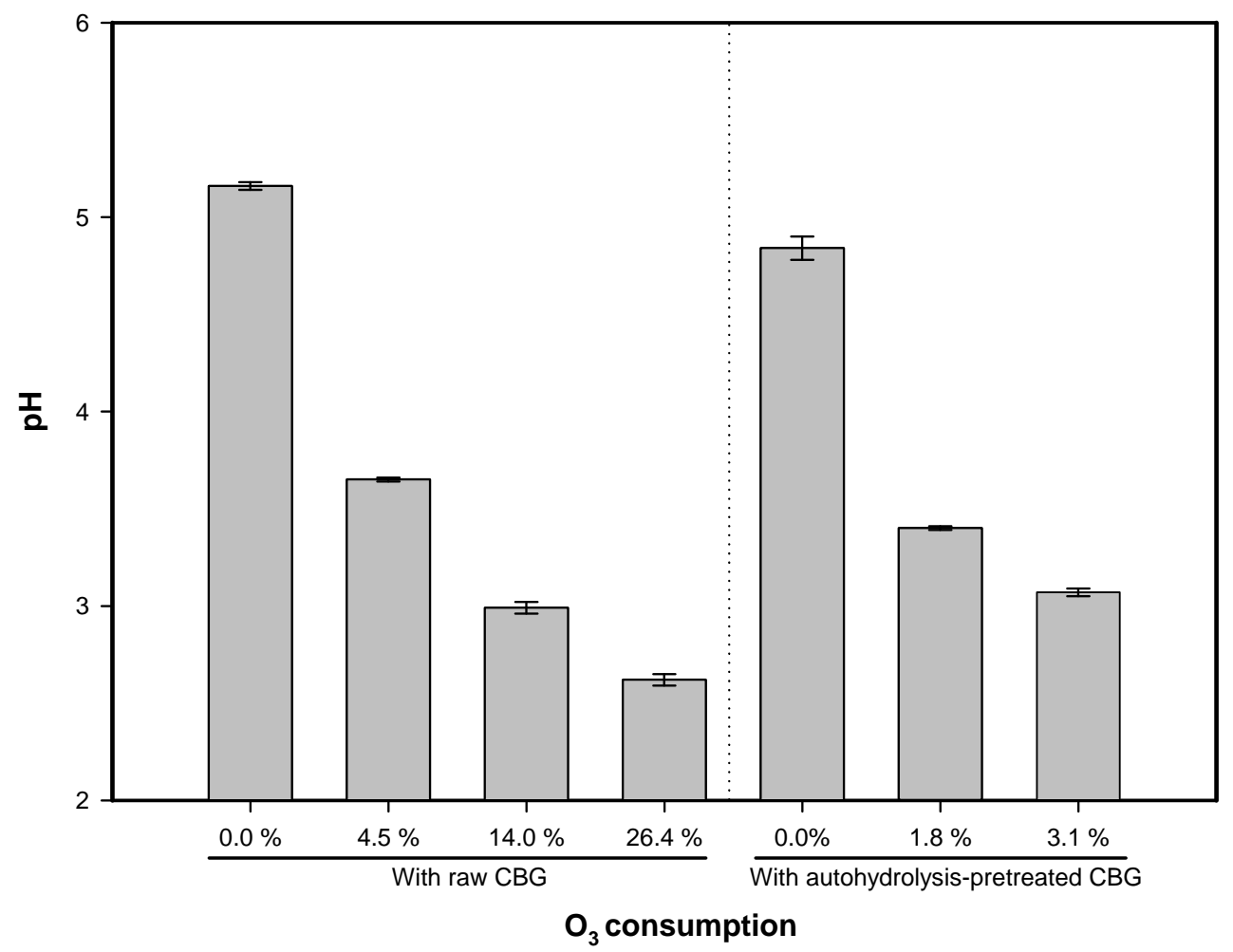

Fig. 4. The $\mathrm{pH}$ of the prehydrolyzate under different ozone conditions

\section{Sugars In Ozonolysis Filtrate}

In order to examine solubilization of the oligo-sugars and mono-sugars from ozone pretreatment, the ozonolysis filtrates were collected and analyzed as shown in Table 3. The raw CBG had 55.6 grams of holocellulose per 100 grams of oven-dry material. After $26.4 \%$ ozone pretreatment, only $0.2 \mathrm{~g}$ of mono-sugars was contained in the ozonolysis filtrate per 100 grams of original raw CBG and even lower amounts for lower ozone dosages (Table 3a). In this study, ozonolysis filtrates were further hydrolyzed using 4\% sulfuric acid. It was assumed that all of the oligo-sugars were converted into their mono-sugars with this treatment. The mono-sugars in the filtrate increased from $0.3 \mathrm{~g}$ to $1.9 \mathrm{~g}$ for increasing ozone consumption from 0 to $26.4 \%$ (Table 3b). Autohydrolysis-treated CBG showed lower mono-sugar contents in the ozone prehydrolyzate (Table $3 \mathrm{~b}$ ) because autohydrolysis treatment with $150^{\circ} \mathrm{C}$ for $60 \mathrm{~min}$ prior ozonolysis extracted some easily solubilized sugars, which were already removed in the autohydrolysis filtrate. 
Table 3a. Sugars in Ozone Prehydrolyzate Filtrate Before Acid-Treated Hydrolysis

\begin{tabular}{|c|c|c|c|c|c|c|c|c|c|c|}
\hline & $\begin{array}{c}\text { Ozone } \\
\text { Cons. (\%) }\end{array}$ & Ara. & Rha. & Gal. & Glu. & Xyl. & Man. & Sum & $\begin{array}{l}\text { Feed }^{* 2)} \\
\text { Glu (\%) }\end{array}$ & $\begin{array}{l}\text { Feed }^{* 3)} \\
\text { Sum (\%) }\end{array}$ \\
\hline \multirow{4}{*}{$\begin{array}{l}R \\
A \\
W\end{array}$} & 0.0 & 0.00 & 0.00 & 0.00 & 0.00 & 0.00 & 0.00 & 0.00 & 0.00 & 0.00 \\
\hline & 4.5 & 0.04 & 0.00 & 0.00 & 0.08 & 0.07 & 0.00 & 0.19 & 0.24 & 0.31 \\
\hline & 14.0 & 0.03 & 0.00 & 0.00 & 0.08 & 0.06 & 0.00 & 0.17 & 0.24 & 0.27 \\
\hline & 26.4 & 0.00 & 0.00 & 0.04 & 0.07 & 0.06 & 0.00 & 0.20 & 0.21 & 0.32 \\
\hline \multirow{2}{*}{$\begin{array}{l}A^{*^{1)}} \\
\mathrm{H}\end{array}$} & 1.8 & 0.00 & 0.00 & 0.00 & 0.00 & 0.01 & 0.00 & 0.01 & 0.01 & 0.02 \\
\hline & 3.1 & 0.00 & 0.00 & 0.00 & 0.01 & 0.02 & 0.00 & 0.03 & 0.03 & 0.05 \\
\hline \multicolumn{11}{|c|}{$\begin{array}{l}\text { Based on } 100 \mathrm{~g} \text { (o.d.) of original raw CBG } \\
\text { 1) autohydrolysis-pretreated CBG } \\
\text { 2) the glucose detected in filtrate }(\mathrm{g}) / \text { total glucose in feed }(\mathrm{g}) \text { in percent } \\
\text { 3) the sum of sugars detected in filtrate }(\mathrm{g}) / \text { total sugars in feed }(\mathrm{g}) \text { in percent }\end{array}$} \\
\hline
\end{tabular}

Table 3b. Sugars in Ozone Prehydrolyzate Filtrate After Acid-Treated Hydrolysis*

\begin{tabular}{|c|c|c|c|c|c|c|c|c|c|c|}
\hline & $\begin{array}{c}\text { Ozone } \\
\text { Cons. (\%) }\end{array}$ & Ara & Rha & Gal & Glu & Xyl & Man & Sum & $\begin{array}{l}\text { Feed }^{\star 2} \text { ) } \\
\text { Glu (\%) }\end{array}$ & $\begin{array}{l}\text { Feed }^{* 3)} \\
\text { Sum (\%) }\end{array}$ \\
\hline \multirow{4}{*}{$\begin{array}{c}\mathrm{R} \\
\mathrm{A} \\
\mathrm{W}\end{array}$} & 0.0 & 0.03 & 0.03 & 0.08 & 0.08 & 0.06 & 0.04 & 0.32 & 0.25 & 0.52 \\
\hline & 4.5 & 0.11 & 0.02 & 0.07 & 0.35 & 0.29 & 0.04 & 0.88 & 1.07 & 1.44 \\
\hline & 14.0 & 0.20 & 0.01 & 0.08 & 0.33 & 0.60 & 0.03 & 1.26 & 1.00 & 2.06 \\
\hline & 26.4 & 0.28 & 0.23 & 0.35 & 1.01 & 0.04 & 0.00 & 1.90 & 3.10 & 3.10 \\
\hline \multirow{2}{*}{$\begin{array}{l}\mathrm{A}^{*^{1)}} \\
\mathrm{H}\end{array}$} & 1.8 & 0.08 & 0.00 & 0.01 & 0.06 & 0.29 & 0.00 & 0.45 & 0.18 & 0.73 \\
\hline & 3.1 & 0.11 & 0.00 & 0.01 & 0.07 & 0.44 & 0.00 & 0.63 & 0.23 & 1.04 \\
\hline \multicolumn{11}{|c|}{$\begin{array}{l}\text { * done by } 4 \% \text { sulfuric acid treatment } \\
\text { 1) autohydrolysis-pretreated CBG } \\
\text { 2) the glucose detected in filtrate }(\mathrm{g}) / \\
\text { 3) the sum of suqars detected in filtrat }\end{array}$} \\
\hline
\end{tabular}

For ozone treatment of raw $\mathrm{CBG}$, the reduction of carbohydrates in the ozonetreated solids increased with ozone consumption up to $6.5 \%$, whereas autohydrolysistreated CBG showed $10 \%$ of carbohydrate reduction regardless of ozone consumption, as shown in Table 4. Of these carbohydrate losses in the solids, a maximum of $26.6 \%$ of these were detected in the filtrate as sugars for the $26.4 \%$ ozone consumption. Only 4$6 \%$ of the carbohydrate losses could be detected as sugars in the ozone filtrate for autohydrolysis-pretreated solids. This suggests that the autohydrolysis followed by ozone produces more byproducts including aromatic acids, aromatic aldehydes, and aliphatic acids than by ozonolysis alone. These byproducts have been detected after autohydrolysis processes (Garrote et al. 2007). 
Table 4. Sugar Recovery from Ozone Filtrate ${ }^{1)}$

\begin{tabular}{|l|c|c|c|c|c|c|}
\hline \multirow{2}{*}{ O3 consumption } & \multicolumn{5}{|c|}{ CBG raw } & CBG from $150^{\circ} \mathrm{C}$ \\
\cline { 2 - 7 } & $0 \%$ & $4.5 \%$ & $14.0 \%$ & $26.4 \%$ & $1.8 \%$ & $3.1 \%$ \\
\hline $\begin{array}{l}\text { Reduced carbohydrate in } \\
\text { pretreated solids (g) }\end{array}$ & $2.4 \pm 0.1$ & $4.3 \pm 0.2$ & $5.6 \pm 0.3$ & $6.5 \pm 0.3$ & $10.0 \pm 0.3$ & $9.8 \pm 0.2$ \\
\hline $\begin{array}{l}\text { Total sugar in hydrolyzed } \\
\text { filtrate after 4\% } \mathrm{H}_{2} \mathrm{SO}_{4}\end{array}$ & 0.29 & 0.80 & 1.14 & 1.73 & 0.41 & 0.58 \\
\hline$\%$ recovered & 12.0 & 18.6 & 20.4 & 26.6 & 4.1 & 5.9 \\
\hline $\begin{array}{l}\text { 1) Average and range of duplicates reported. Sugar was expressed as oligo-sugar forms. Basis } \\
\text { of 100 grams of solids to ozonolysis } \\
\text { 2) Calculated by (holocellulose content of raw material - holocellulose content of pretreated } \\
\text { solid at each condition) }\end{array}$
\end{tabular}

\section{Effect of Ozonolysis Condition on Enzymatic Hydrolysis}

Ozonolysis significantly improved the cellulose conversion with subsequent enzymatic hydrolysis. The $0 \%$ ozone dosage had an observed cellulose conversion of $24 \%$, based on the raw CBG cellulose content (Figure 5a). Ozone pretreatment of CBG increased the theoretical cellulose conversions from $30 \%$ at $4.5 \%$ ozone consumption to $53 \%$ at $26.4 \%$ ozone consumption. Autohydrolysis-pretreated CBG had a $46 \%$ theoretical cellulose conversion. Autohydrolysis followed by $3.1 \%$ ozone had a $61.3 \%$ theoretical cellulose conversion. Similar to cellulose conversions, higher dosages of ozone produced higher xylan to xylose conversions relative to the $0 \%$ ozone consumption (Figure $5 \mathrm{~b}$ ). Ozone (3.1\%) pretreatment of the autohydrolysis-pretreated CBG resulted in the highest hemicellulose conversion of $27.4 \%$. Since the $\mathrm{pH}$ dropped from 7.0 to 2.6 with the $26.4 \%$ consumption of ozone, it was suspected that this condition might produce toxic inhibitors for subsequent enzymatic hydrolysis or fermentation. However, the cellulose and xylose conversions were the highest for the $26.4 \%$ ozone consumed samples.

\section{Material Balance}

A material balance of the ozone pretreatment process and subsequent enzymatic hydrolysis was performed for all pretreatment conditions (Table 5). The material balance was able to track greater than $97 \%$ of the total solids through the process. The $3.1 \%$ ozone dosage of autohydrolysis-pretreated CBG with a subsequent enzyme hydrolysis (10 FPU) on the ozone-pretreated solids and a post-hydrolysis on the combined autohydrolysis and ozone filtrates provided the highest sugar recovery. A total of 24.5 grams of sugars under this condition can be recovered, which is $40.1 \%$ of the theoretical sugar yield. Autohydrolysis alone followed by enzyme hydrolysis (10 FPU) provided a sugar recovery of $36.4 \%$, which was higher than any ozone treatment of raw CBG followed by enzyme hydrolysis (Table 5a) and near equivalent to any autohydrolysis followed by ozone and enzyme hydrolysis (Table 5b). This indicates that there are distinct cost advantages to autohydrolysis alone and that the application of ozone at $\$ 0.80$ per pound is not an advantageous method to improve enzyme accessibility of CBG. 
Table 5a. Material balances from ozone pretreatments with raw CBG followed by enzyme treatment

\begin{tabular}{|c|c|c|c|c|c|c|c|c|c|c|c|c|}
\hline \multirow{2}{*}{$\begin{array}{c}\text { O3 consumption } \\
(\%)\end{array}$} & \multirow{2}{*}{$\begin{array}{l}\text { Pretreated } \\
\text { Solids (g) }\end{array}$} & \multirow{2}{*}{$\begin{array}{l}\text { Filtrates } \\
\text { (g) }\end{array}$} & \multirow{2}{*}{$\begin{array}{l}\text { Recovery } \\
(\%)\end{array}$} & \multicolumn{3}{|c|}{ Sugars in Filtrates (g) } & \multirow{2}{*}{ FPU } & \multicolumn{3}{|c|}{ Enzyme Hydrolyzate (g) } & \multicolumn{2}{|c|}{ Sugar recovery } \\
\hline & & & & $\mathrm{G}^{1)}$ & $\mathrm{H}^{2)}$ & $\mathrm{T}^{3)}$ & & $G^{1)}$ & $\mathrm{H}^{2)}$ & $\mathrm{T}^{3)}$ & $(g)^{4)}$ & $(\%)^{5)}$ \\
\hline 0.0 & 93.1 & 6.9 & 100 & 0.08 & 0.24 & 0.32 & 10 & 7.72 & 0.22 & 7.94 & 8.26 & 13.5 \\
\hline 4.5 & 91.0 & 8.6 & 99.6 & 0.35 & 0.53 & 0.88 & 10 & 6.89 & 0.73 & 7.63 & 8.51 & 13.9 \\
\hline 14.0 & 87.2 & 12.7 & 99.9 & 0.33 & 0.93 & 1.26 & 10 & 15.41 & 3.01 & 18.42 & 19.68 & 32.2 \\
\hline 26.4 & 84.7 & 15.3 & 100 & 1.01 & 0.89 & 1.90 & 10 & 11.81 & 2.60 & 14.41 & 16.31 & 26.7 \\
\hline
\end{tabular}

Table 5b. Material balances from ozone pretreatments with autohydrolysis-treated CBG followed by enzyme treatment

\begin{tabular}{|c|c|c|c|c|c|c|c|c|c|c|c|c|}
\hline \multirow{2}{*}{$\begin{array}{c}\mathrm{O} 3 \text { consumption } \\
(\%)\end{array}$} & \multirow{2}{*}{$\begin{array}{l}\text { Pretreated } \\
\text { Solids }(\mathrm{g})\end{array}$} & \multirow{2}{*}{$\begin{array}{l}\text { Filtrates } \\
\text { (g) }\end{array}$} & \multirow{2}{*}{$\begin{array}{l}\text { Recovery } \\
(\%)\end{array}$} & \multicolumn{3}{|c|}{ Sugars in Filtrates (g) } & \multirow{2}{*}{ FPU } & \multicolumn{3}{|c|}{ Enzyme Hydrolyzate (g) } & \multicolumn{2}{|c|}{ Sugar recovery } \\
\hline & & & & $\mathrm{G}^{1)}$ & $\mathrm{H}^{2)}$ & $\mathrm{T}^{3)}$ & & $\mathrm{G}^{1)}$ & $\mathrm{H}^{2)}$ & $\mathrm{T}^{3)}$ & $(g)^{4)}$ & $(\%)^{5)}$ \\
\hline 0.0 & 78.9 & 19.9 & 98.9 & 2.63 & 2.28 & 4.92 & 10 & 14.08 & 3.27 & 17.35 & 22.27 & 36.4 \\
\hline 1.8 & 74.7 & 23.0 & 97.7 & 2.69 & 2.67 & 5.36 & 10 & 14.96 & 2.87 & 17.83 & 23.19 & 37.9 \\
\hline 3.1 & 74.9 & 23.2 & 98.1 & 2.70 & 2.84 & 5.54 & 10 & 15.60 & 3.36 & 18.97 & 24.51 & 40.1 \\
\hline
\end{tabular}




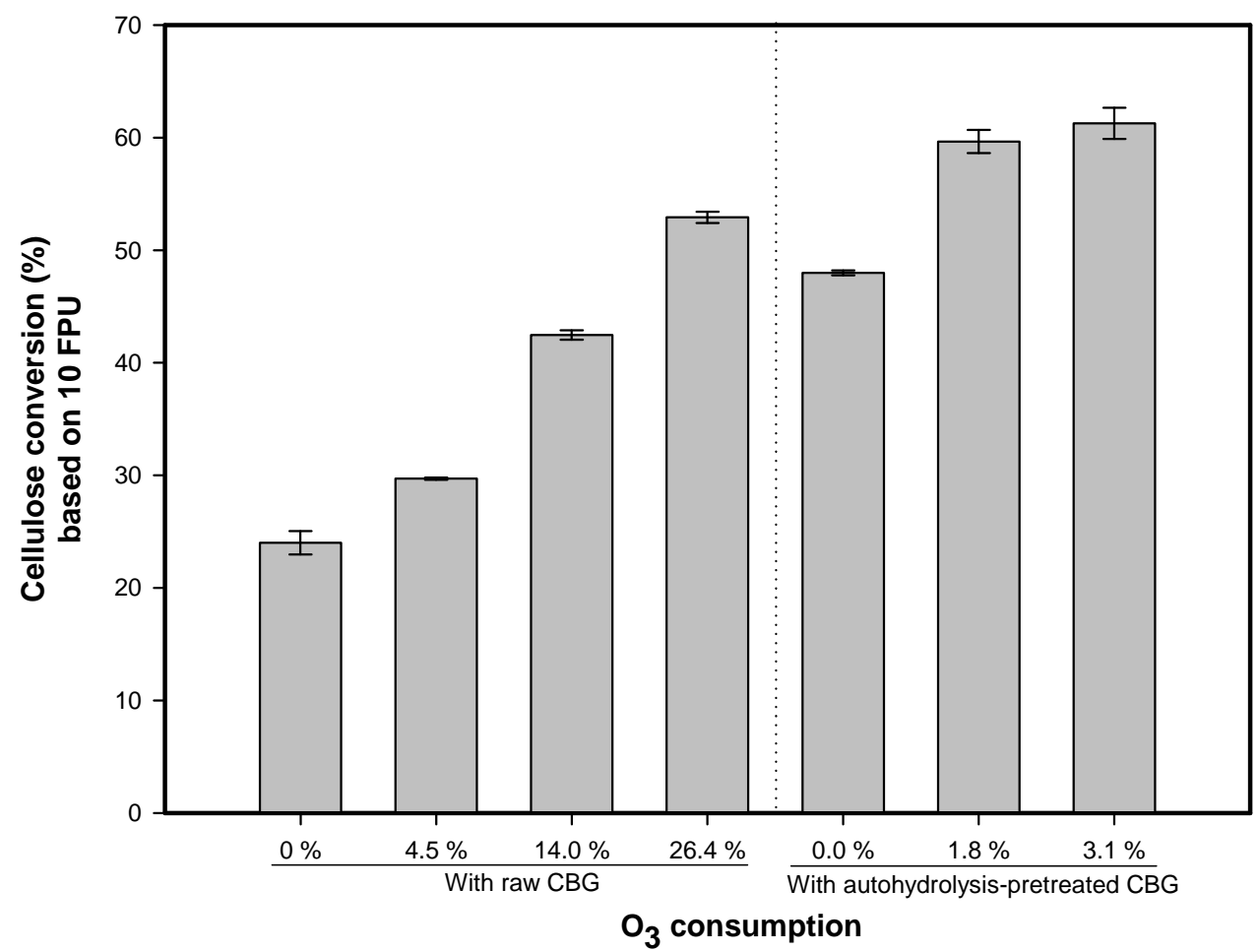

a) cellulose conversion

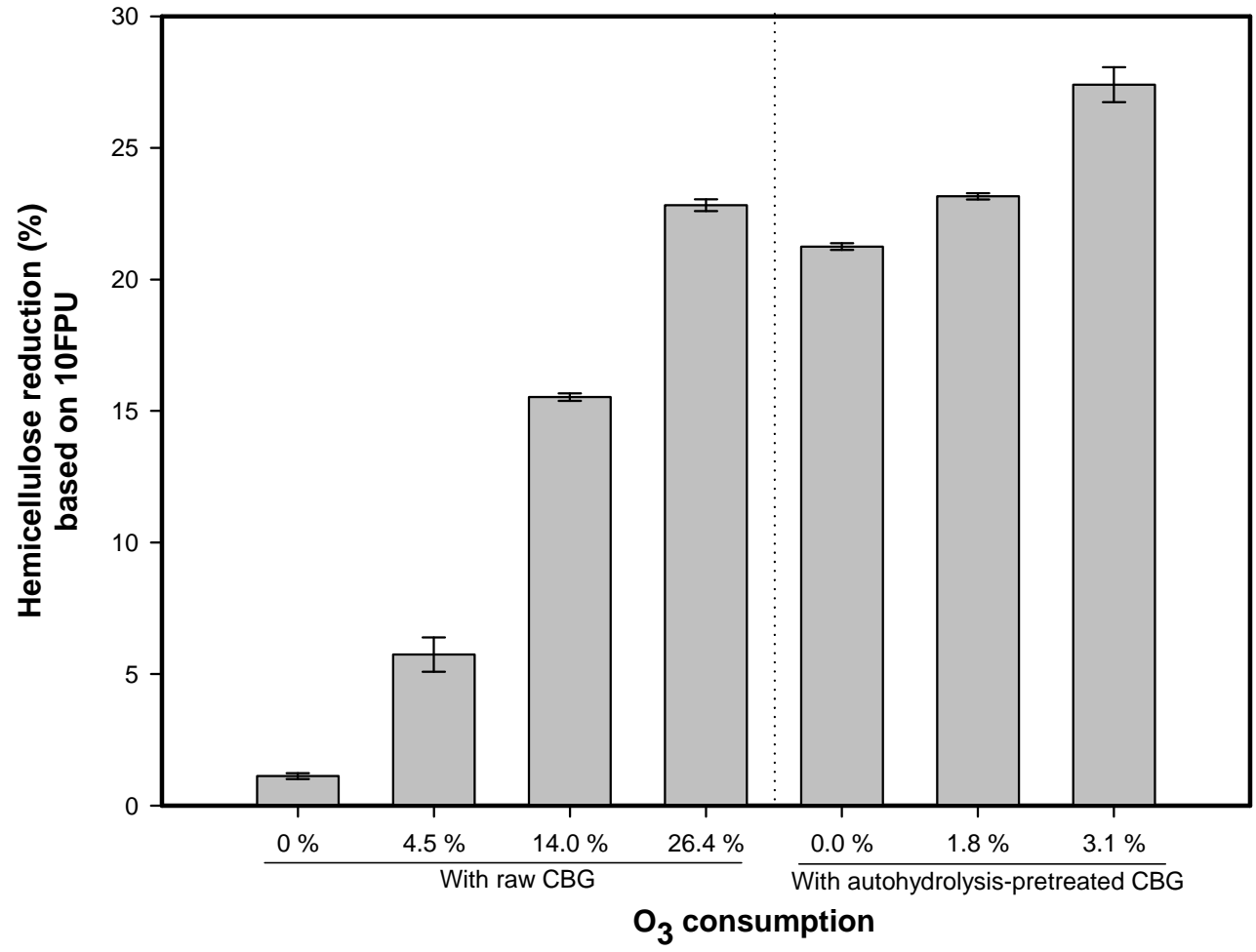

b) hemicellulose conversion

Fig. 5. Effect of ozone on enzymatic hydrolysis with 10 FPU: a) cellulose conversion; b) hemicellulose conversion. 


\section{CONCLUSIONS}

1. Ozone pretreatment of coastal Bermuda grass (CBG) removed a significant amount of the lignin and hemicellulose in both raw $\mathrm{CBG}$ and autohydrolysis-treated CBG.

2. Autohydrolysis of $\mathrm{CBG}$ increased the reactivity of cellulose, hemicellulose, and lignin with ozone.

3. Increased ozonation marginally increased the enzyme accessibility and the total sugar recovery of the $\mathrm{CBG}$.

4. Autohydrolysis pretreatment alone is as effective as the ozone pretreatments with experimental conditions studied herein. The combination of autohydrolysis followed by ozone has higher sugar conversions via enzymatic hydrolysis than ozone alone.

\section{ACKNOWLEDGMENTS}

The authors would like to thank North Carolina Biotech Center for funding this collaborative research project between Dr. Jay J. Cheng of the Biological and Agricultural Engineering Department and the authors of this manuscript in the Forest Biomaterials Department at North Carolina State University, NCBC Grant \# 2007-MRG1106. Also thanks to Novozymes Inc for providing enzyme samples.

\section{REFERENCES CITED}

Akin, D. E., and Morrison, W. H. (1988). "Ozone treatment of forage: Structure and digestibility of different types of lignified cell walls," Crop Sci. 28, 337-342.

Ben-Ghedalia, D., and Miron, J. (1981). "Effect of sodium hydroxide, ozone and sulphur dioxide on the composition and in vitro digestibility of wheat straw," J. Sci. Food Agric. 32(3), 224-228.

Ben-Ghedalia, D., and Shefet, G. (1983). "Chemical treatments for increasing the digestibility of cotton straw: 2 . Effect of ozone and sodium hydroxide treatments on the digestibility of cell-wall monosaccharides," J. Agric. Sci. 100, 401-406.

Coughlan, M. P. (1992). "Enzymic hydrolysis of cellulose: An overview," Bioresour. Technol. 39(2), 107-115.

Ehrman, T. (1994). "Method for determination of total solids in biomass," In: Laboratory Analytical Procedures No. 001, National Renewable Energy Laboratory, Golden, CO.

Ehrman, T. (1996). "Method for determination of acid-soluble lignin in biomass," In: Laboratory Analytical Procedures No. 004, National Renewable Energy Laboratory Golden, CO.

Eisenhauer, H. R. (1971). "Increased rate and efficiency of phenolic waste ozonation," $J$. Water Pollut. Control Fed. 43, 200-208.

Garcia-Cubero, M.A., Gonzalez-Benito, G., Indacoechea, I., Coca, M., and Bolado, S. (2009). "Effect of ozonolysis pretreatment on enzymatic digestibility of wheat and rye straw," Bioresour. Technol. 100(4), 1608-1613. 
Garrote, G., Falque, E., Dominguez, H., and Parajo, J. C. (2007). "Autohydrolysis of agricultural residues: Study of reaction byproducts,” Bioresour. Technol. 98(10), 1951-1957.

Ghose, T. K. (1987). “Measurement of cellulase activities,” Pure \& Appl. Chem. 59(2), 257-268.

Gould, J. P., and Weber, W. J., Jr. (1976). “Oxidation of phenols by ozone,” J. Water Pollut. Control Fed. 48(1), 47-60.

Hendriks, A. T. W. M., and Zeeman, G. (2009). "Pretreatments to enhance the digestibility of lignocellulosic biomass," Bioresour. Technol. 100(1), 10-18.

Iyer, P. V., and Lee, Y. Y. (1999). "Product inhibition in simultaneous saccharification and fermentation of cellulose into lactic acid," Biotechnol. Lett. 21, 371-373.

Kojima, Y., and Yoon, S.-L. (2008). "Improved enzymatic hydrolysis of waste paper by ozone pretreatment," J. Mater. Cycles Waste Manag. 10, 134-139.

Kratzl, K. Claus, P., and Reichel, G. (1976). "Reactions of lignin and lignin model compounds with ozone," Tappi 59(11), 86-87.

Lee, J. M., Shi, J., Venditti, R. A., and Jameel H. (2009). “Autohydrolysis pretreatment of Coastal Bermuda grass for increased enzyme hydrolysis," Bioresour. Technol. 100(24), 6434-6441.

Lee, J. M., Jameel, H., and Venditti, R. A. (2010). “A comparison of the autohydrolysis and ammonia fiber explosion (AFEX) pretreatment on the subsequent enzymatic hydrolysis of coastal Bermuda grass," Bioresour. Technol. 101(14), 5449-5458.

Liebergott, N., and van Lierop, B. (1978). "The use of ozone in bleaching and brightening wood pulps," Oxygen, Ozone and Peroxide Pulping and Bleaching Seminar, TAPPI, New Orleans, LA, p. 90.

Morrison, W. H. III, and Akin, D. E. (1990). "Water-soluble reaction products from ozonolysis of grasses," J. Agric. Food Chem. 8, 687-681.

Mosier, N., Wyman, C., Dale, B., Elander, R., Lee, Y.Y., Holtzpple, M., and Ladisch, M. (2005). "Features of promising technologies for pretreatment of lignocellulosic biomass," Bioresour. Technol. 96, 673-686.

Neely, W. C. (1984). "Factors affecting the pretreatment of biomass with gaseous ozone," Biotechnol. Bioeng. XXVI, 59-65.

Pan, G. Y., Chen, C.-L., Chang, H.-M., and Gratzl, J. S. (1984). "Studies on ozone bleaching. 1. The effect of $\mathrm{pH}$, temperature, buffer systems and heavy metal-ions on stability of ozone in aqueous solution," J. Wood Chem. Tech. 4(3), 367-387.

Quesada J., Rubio, M., and Gómez, D. (1999). "Ozonation of lignin rich solid fractions from corn stalks." J. Wood Chem. Tech. 19, 115-137.

Silverstein, R. A., Chen, Y., Sharma-Shivappa, R. R., Boyette, M. D., and Osborne, J. (2007). "A comparision of chemical pretreatment methods for improving saccharification of cotton stalks," Bioresour. Technol. 98, 3000-3011.

Sun, Y., and Cheng, J. (2002). "Hydrolysis of lignocellulosic materials for ethanol production: a review," Bioresour. Technol. 83, 1-11.

Templeton, D., and Ehrman, T. (1994). "Determination of acid-insoluble lignin in biomass," In: Laboratory Analytical Procedures No. 003, National Renewable Energy Laboratory Golden, CO. 
US-DOE (2005). "Biomass as a feedstock for a bioenergy and bioproducts industry: the technical feasibility of a Billion-Ton annual supply," US Department of Energy. Oak ridge National laboratory, Oak ridge, TN. DOE/GO-102995-2135, (http://www1.eere.energy.gov/biomass/pdfs/final_billionton_vision_report2.pdf).

Vidal, P.F., and Molinier, J. (1988). "Ozonolysis of lignin-improvement of in vitro digestibility of poplar sawdust," Biomass 16, 1-17.

Article submitted: Feb. 2, 2010; Peer review completed: March 18, 2010; Revised version received and accepted: April 9, 2010; Published: April 12, 2010. 